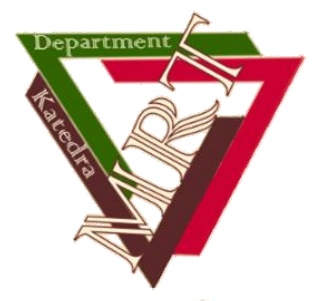

\title{
Recycling and Sustainable Development
}

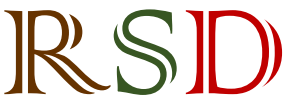

Online ISSN 2560-3132

Print ISSN 1820-7480

\section{Determination of circularity indicators - a case study of MB International Company}

\author{
Angelina Pavlović a, \#, Goran Bošković a , Nebojša Jovičić a , Snežana Nestić a, \\ Natalia Sliusar $^{\text {b }}$, Nemanja Stanisavljević ${ }^{c}$ \\ ${ }^{a}$ University of Kragujevac, Faculty of Engineering, Serbia \\ b Perm National Research Polytechnic University, Environmental Protection Department, Russia \\ ${ }^{c}$ University of Novi Sad, Faculty of Technical Sciences, Serbia
}

\section{A R T I C L E I N F O}

Received 30 June 2020

Accepted 25 September 2020

Research article

Keywords:

Circular economy

Circularity Indicators

Material Circularity Indicator

Sustainable development

Extended and revised version of a conference article - presented in $3^{\text {rd }}$ ICQL

\begin{abstract}
A B S T R A C T
The circular economy (CE) is currently a worldwide popular concept that should ensure sustainable development and resource efficiency. It is established on the theory of consumption and use of resources in the process of production in a way that affects a limitation of adverse effects on the environment. Simultaneously, this concept creates additional value and reuse of the products. In the Republic of Serbia (RS), the idea of CE is still new and underdeveloped. Hence, this paper aims to explore the possibility of implementing a CE in companies that operate in the RS by adopting the already developed methodology in the European Union. This research was conducted by monitoring the production process in the company "MB INTERNACIONAL" that produced cardboard packaging. The obtained approximate value of Circular Indicator of this company was 0.47 , which indicated that the company had excellent chances for full implementation of the CE model in the business with the application of specific measures. The low-budget and highbudget measures, which could improve the circularity level in the analyzed company, are also presented in the research.
\end{abstract}

\section{Introduction}

Found on the latest available United Nations report, the total population of the world exceeded 7.7 billion in 2019 (United Nations, 2019). The growth of the population results in problems and risks which endanger the environment and affect the inability to achieve sustainable development. In order to eliminate those problems or reduce them, it is necessary to make specific changes and modifications to the current economic model to improve the environment's quality.

The current global economic model entitled the linear economy model (LEM) is based on the "take-make/usedispose" principles (Levoso et al., 2019).

There are many diverse negative outcomes from the take-make/use-dispose linear economy model (Andrews, 2015). The LEM consists of one linear flow of the materials that is not sustainable: the extraction of resources and their use in production, distribution of products, market placement, use of products by consumers, and finally, product disposal in the form of waste. Improvement of the said model can be achieved by different preventive measures that have defined the modern concept of economy named circular economy

\footnotetext{
\# Corresponding autor: angelina.pavlovic@uni.kg.ac.rs
} 
model - that has the potential to lead to sustainable development while decoupling economic growth from the negative consequences of resource depletion and environmental degradation (Morseletto, 2020).

The circular economy model represents the model which replaces the end-of-life concept with restoration, shifts towards the use of renewable energy, eliminates the use of toxic chemicals, which impair reuse and return to the biosphere, and aims for the elimination of waste through the superior design of materials, products, systems, and business models (EMAF, 2013). The transition from a linear to a circular economy represents a systemic change that builds long-term business and economic reforms and provides environmental and social benefits. Implementation of the $\mathrm{CE}$ is a very complex activity because it requires changes in the whole chain of product values: design and new business models, new ways of transforming waste into resources, new ways of consumer behavior, etc. The circular economy focuses on the efficient use of materials, reduction of waste and recycling of materials (Kirchherr et al., 2017).

The Republic of Serbia needs to align the national legislation with the European Union (EU), as a candidate for the EU membership. That implies harmonizing legislation in all fields, including the field of environmental protection. In the analyzed area, EU "Circular Economy Action Plan: For a cleaner and more competitive Europe" (European Commission, 2020) should be included in the Serbian policy. This plan has been built on the work done since 2015 when the first version of the action plan "Closing the loop - An EU action plan for the Circular Economy COM/2015/0614 final" was adopted (European Commission, 2015). The action plans for the CE launched by European Commission define concrete and ambitious programs, with measures covering the entire life cycle of a product, from production and consumption to waste management and the secondary raw material market.

According to this action plan, estimation of the level of circularity in companies should be executed. Today, in the Republic of Serbia, there is no tool available to assess the economic and environmental performance of circular systems. Consequently, the motivation for this research is represented by the fact that there are still no officially developed indicators related to the circular economy in the Republic of Serbia. For that purpose, the adoption of the existing "Circularity Indicators" was made. The methodology was developed by the EMF and Granta in the MCI project's context aiming to find indicators to measure how well a product performs in the CE system (EMAF, 2015).

\section{Theoretical framework}

The CE represents a contrast to today's model of the economy that includes the uncontrolled exploitation of natural material and its flow from the factory across consumer to the landfill (Đurić et al., 2017). An idea of the CE evolved from the fact that waste does not exist in nature. The cycles in nature (e.g. water cycles, nutrient cycles) exist to help the waste of one cycle become the resource of the other (Patwa et al., 2020).

Based on the question of why the concept of circular flows of natural materials was not applied in production processes, the CE began to evolve. A CE is characterized as an economy that is regenerative by design aimed to retain as much value as possible of products, parts, and materials. In other words, to create a system that allows for the long life, optimal reuse, refurbishment, remanufacturing, and recycling of products and materials (EMAF, 2016; Kraaijenhagen et al., 2016). The main goal of a circular economy is to protect the environment against any form of degradation and to improve the socioeconomic conditions of a particular society (Solaja, 2019).

The development of CE cannot possibly be related to one single date or one individual researcher. Many scientists claim that Pearce and Turner were first to establish the concept of CE. They made the theoretical framework based on previous studies of the scientist Kenneth Boulding (Pearce and Turner, 1990), but they were not recognized as founders of the CE concept.

Germany was the first country to formally accept the $\mathrm{CE}$ concept and incorporate ideas of the concept into its legislation. The CE concept was defined in The law of closed substance cycle and The waste management act in 1996 (El-Haggar, 2007). Japan did the same thing in 2000 by adopting The fundamental requirement for establishing the recycling-based society (Radivojević, 2018). Today, the People's Republic of China and the European Union have achieved the most significant progress in the transition from the linear to the circular economy (McDowall et al., 2017; Ghisellini and Ulgiati, 2020). This significant progress is reflected in developed policy regulations and documents, academic publications and media articles, as well as by developing metrics and indicators that monitor the performance of the economy regarding the scale of primary materials use, waste flows, and recycling and circularity. If the $\mathrm{CE}$ in the Republic of Serbia is considered, it can quickly be concluded that it is in the initial phase.

In recent years, in Serbia, the benefits of CE for the environment, economic growth, and creation of new jobs have been recognized, which led to some programs that had already begun. Typical examples are preparation of "The strategy for introducing $\mathrm{CE}$ into the waste management sector in Serbia", project "Circular Economy Platform for Sustainable Development in Serbia", an "EX-ante analysis of the circular economy effects", and "Road Map for Circular Economy in Serbia". It is necessary to significantly increase awareness and knowledge of the concepts of a circular economy, both for civil servants and for policymakers, so that the government institutions can improve work in this field (Ullstein et al., 2019). In the Republic of Serbia, the 
most commonly used definition of the CE concept is "the approach in the production that transforms the function of resources - waste from the facilities becomes valuable material in other production processes, and the products themselves can be repaired, reused, or improved instead of being disposed of" (Đureta et al., 2016).

Today, the main focus of academia is to analyze the progress of the transition towards CE (Kalmykova et al., 2018). Suitable methods, tools, and indicators are necessary to quantify the progress of the transition to a circular economy. The problem appears in the fact that, according to the report of Monitoring and advancing the $\mathrm{CE}$ transition, there is no recognized way of measuring the effectiveness of the European Union, a country, or even a company's progress of the transition to a circular economy. Also, holistic monitoring tools for supporting such a process do not exist (Saidani, 2018). The methodologies for determining a level of circularity in one production process are not yet sufficiently developed. Namely, only a small number of conducted researches considers circular economy indicators.

The problem that occurs with the lack of tracking and evaluation of circularity was determined by the foundation Ellen MacArthur (EMAF), and having this in mind, the foundation launched and published the project "Circularity indicators" for the first time in 2015. This project aimed to solve the problem of missing indicators in the field of CE and develop a methodology that should estimate the progress of companies in transition from linear into a circular model of running a business. There is a deficit of research in RS on the topic of evaluating the circularity level in the companies so the primary contribution of this research is checking whether methodology launched by EMAF can be adopted in Serbian policy.

\section{Problem statement}

The adoption of CE on macro and micro levels brings numerous benefits, which can be classified into three primary groups: economic, social, and ecological. However, there are specific barriers for the further development of the CE. Lack of legal regulation in this area is more indicative, as well as the lack of indicators to determine the level of circularity of organizations.

Monitoring or tracking progress towards a $\mathrm{CE}$ is a challenging and difficult task because the development of a $\mathrm{CE}$ is not limited to certain materials, products, or sectors. It is considered to be a systemic change that affects the entire economy and includes all products and services in different sectors (European Commission, 2018).

So this research aims to provide adoption of the methodology "Circularity indicators" for determining the level of circularity for companies that operate in the Republic of Serbia, as well as defining measures to improve their circular economy model (Pavlović et al.,
2018). Based on the mentioned adoption of the methodology, it is achievable to determine the possibility of implementing a $\mathrm{CE}$ in companies that are operating in the RS. Namely, according to the level of achieved circularity, it is possible to determine how far the economic business model of the analyzed company is from the circular one and whether the transformation towards the circular model is possible at all.

\section{Circularity assessment in companies}

The circularity assessment of companies is a highly complex process due to the complexity of determining valid indicators. As a starting point in this research, indicators developed by the European Commission Environment Program partnered with the EMAF and Granta Design on the LIFE+ Project (Cayzer et al, 2017) were used. Publication "Circularity indicators" represents a methodology about defining a material circularity indicator (MCI) of the product/company and about setting the complementary indicators (CIs). The CIs are used to identify relevant risks and impacts of the product, but in this research, CIs were not considered. Based on the publication of "Circularity Indicators", for determining the levels of circularity of the company, at first, it is necessary to assess the circularity level of all products which are produced by the company.

MCI and Linear Flow Index (LFI) indicators are the most significant indicators for determining the circularity level of a company. This is explained by the fact that results of MCI and LFI indicators can be used in the design of new products to take circularity into account as a criterion and input for design decisions. Also, using these indicators companies could be able to parallel different products regarding their circularity.

The MCI is the leading indicator, and it gives information about the product's materials circulate level. The obtained result of the MCI can be in a range from 0 (pure linearity) to 1 (pure circularity). The MCI is evolved to enable companies to understand how far they are from linear to circular model (EMAF, 2015). A higher value of the MCI shows a higher level of circularity.

The material circularity indicator is built from specific data that influence the characteristics of a product (EMAF, 2015; Bracquené et al., 2020):

- mass of virgin raw material used in production process (\% of raw, recycled, and reused material),

- mass of unrecoverable waste that is associated with the product's life cycle,

- utility factor that accounts for the length and intensity of the product's use, and

- efficiency of recycling processes.

Based on the previous list, the MCI is estimated from the virgin, reused, and recycled input of the feedstock as well as the reused input. It considers the usage length and 
intensity, and finally, the end-of-life scenario (Dwek, 2017).

Another important indicator for the circularity level in one company is LFI. LFI measures the proportion of material sourced from virgin materials, ending up as unrecoverable waste, so-called linear part of material flow (EMAF, 2015).

For the development of the circular economy model, it is necessary that the MCI has a value close to 1 and that the LFI has a value approximately equal to 0 .

The analyzed circularity indicators (MCI and LFI) have an impact on material sourcing and product design (environmental footprint, energy consumption, level of recycling, water consumption, the price of materials, revenue, etc.).

The methodology for circularity indicators used in this research for the Serbian company presents an adoption of the methodology mentioned above in a specific company. The adoption of a methodology "Circularity Indicators" in companies is significant for its management to identify products that need to improve the circular rate. Table 1 presents the identified strengths and weaknesses of the analyzed methodology.

The following steps show a brief overview of the methodology developed by EMAF (EMAF, 2015).

Step 1. The first step determines the mass of virgin feedstock (V). This mass can be determined by equation 1 , where $\mathrm{M}$ represents the mass of the final product, while $F_{R}$ and $F_{U}$ represent the fraction from recycled and reused sources, respectively:

$$
V=M \cdot\left(1-F_{R}-F_{U}\right)
$$

Step 2. The second step consists of determining the mass of unrecoverable waste through a product's material going into a process where the materials are no longer recoverable $\left(W_{O}\right)$. That mass can be specified by equation 2. Similar to the previous case, $C_{R}$ and $C_{U}$ represent the fragment of the mass of a product being collected for a recycling process, i.e., for a process of reuse.

$$
W_{O}=M \cdot\left(1-C_{R}-C_{U}\right)
$$

Step 3. The third step presents the estimation of the efficiency of recycling process $\left(E_{C}\right)$. Equation 3 shows the ratio of the mass of useful recycled components and the mass of all fraction entering the recycling process per period, $\sum m_{i}($ out $)$ and $\sum m_{i}($ in $)$.

$$
E_{C}=\frac{\sum m_{i}(o u t)}{\sum m_{i}(i n)} \cdot 100 \%
$$

Step 4. The fourth step determines the mass of unrecoverable waste generated in the recycling process of a product $\left(W_{C}\right)$. This parameter can be explained by equation 4.

$$
W_{C}=M \cdot\left(1-E_{C}\right) \cdot C_{R}
$$

Step 5. The fifth step is related to specifying the mass of unrecoverable waste generated when producing recycled feedstock for a product $\left(W_{F}\right)$. The parameter $E_{F}$ has an essential role in equation 5 , and it represents the efficiency of the recycling process used to produce recycled feedstock for the material. $E_{F}$ can be determined the same way as the parameter $E_{C}$.

$$
W_{F}=M \cdot \frac{\left(1-E_{F}\right) \cdot F_{R}}{E_{F}}
$$

Step 6. The sixth step refers to establishing the mass of unrecoverable waste connected to all life cycles of a product $(W)$, and it is given by equation 6 .

$$
W=W_{O}+\frac{W_{F}+W_{C}}{2}
$$

Step 7. The seventh step determines of linear index flow shown by equation 7 .

$$
L F I=\frac{V+W}{2 \cdot M+\frac{W_{F}-W_{C}}{2}}
$$

Step 8. The eight step shows how to determine the utility of a product $(X)$, and it is given by equation $8 . X$ depends on four parameters that are related to the actual average lifetime of a product and an industry-average product of the same type $\left(L, L_{a v}\right)$ and the actual average number of functional units achieved during the use phase

\begin{tabular}{|c|c|c|}
\hline & ths & \\
\hline $\begin{array}{l}\text { Methodology } \\
\text { "Circularity } \\
\text { Indicators" }\end{array}$ & $\begin{array}{l}\text { - The calculation methodology is available. } \\
\text { - Repair and remanufacture can be included by } \\
\text { adapting the product lifetime and/or component } \\
\text { reuse. However, the current methodology does not } \\
\text { incorporate a more detailed modelling of repair or } \\
\text { remanufacturing. } \\
\text { - A simple interpretation of the indicators. }\end{array}$ & $\begin{array}{l}\text { - Only includes material flows, no toxicity, } \\
\mathrm{CO}_{2} / \text { energy, scarcity and water. } \\
\text { - Circularity indicators on their own are not beatific, } \\
\text { it should be seen in the context and be used with } \\
\text { complementary indicators. } \\
\text { - Software by which these indicators can be } \\
\text { automatic used is not open source. }\end{array}$ \\
\hline
\end{tabular}
of a product and the industry-average product of the same type $\left(U, U_{a v}\right)$.

$$
X=\left(\frac{L}{L_{a r}}\right) \cdot\left(\frac{U}{U_{a r}}\right)
$$

Table 1

Strengths and weaknesses of methodology that use MCI and LFI indicators (Vercalsteren et al., 2018) 
Step 9. Equation 9 represents the way of calculating the $\mathrm{MCI}_{\mathrm{P}}$. It depends on the linear flow index and utility factor $F(X)$.

$$
M C I_{P}^{*}=1-L F I \cdot F(X)
$$

Utility factor is defined as a function of the utility of the product. In order to improve the utility of the product, EMAF has adopted the function $F(X)$ that is similar to equation 10.

$$
F(X)=\frac{0.9}{X}
$$

Equation 9 is transformed into equation 10 in order to avoid a possibility that $M C I_{P}$ value can be negative for products with the mostly linear flow and a utility worse than the average product. Namely, equation 10 is defined in such a way that $M_{P} I_{P}$ takes, by convention, the value 0.1 for an entirely linear product (i.e., $L F I=1$ ) whose utility equals the industry average (i.e., $X=1$ ) (Marvuglia et al., 2018; Razza et al., 2020).

Finally, $M C I_{P}$ is defined as:

$$
M C I_{P}=\max \left(0, M C I_{P}^{*}\right)
$$

Step 10. The material circularity indicator of a company $M C I_{C}$ can be determined by the $M C I_{P}$.

Also, in order to evaluate $M C I_{C}$, it is necessary to determine the normalizing factor. It is used to aggregate $M C I_{P}$ using a weighted average approach. The sum of normalizing factor consists out of the normalizing factor $N_{R(i)}$ of reference products for product range $P_{(i)}$. The index $i$ notes to a specific product range or department.

Finally, equation 12 gives the form for calculating the company's material circularity indicator:

$$
M C I_{C}=\frac{1}{\sum N_{R(i)}} \sum\left(N_{R(i)} \cdot M C I_{P(i)}\right)
$$

\section{Application of "Circularity indicators" methodology in Serbian companies}

For the implementation of the $\mathrm{CE}$ in companies in the Republic of Serbia, systemic changes in the legislation are needed, as well as the adoption of uniform indicators for monitoring $\mathrm{CE}$ at the macro, micro, and nano levels.

\subsection{Case study}

The company that was chosen for determining the level of circularity in Serbia is "MB INTERNACIONAL". The main activity of "MB INTERNACIONAL" is the production of the packaging made from paper and cardboard and the production of the cupcake liner. In the analyzed company, the procedure of the methodology
"Circularity Indicators" was realized in the following order:

Step 1. Primarily, the inventory list was created. The inventory list included a list of all products that were manufactured in the analyzed period. The inventory list of the company "MB INTERNACIONAL" consisted out of 41 products.

Step 2. The second step was to create groups of related products. Products within one group were sorted by the criterion of similarity of material composition (for example, a criterion of similarity can be a type of material and their relative mass).

The analyzed company products range was divided into eight groups:

1) cardboard plates,

2) printed cardboard plates,

3) boxes for rolls and cakes,

4) boxes for cookies,

5) boxes for cakes with an opening,

6) cake pads,

7) cupcake and cookies liner, and

8) party program.

Step 3. The third step involved creating standard accounting information in the form of a table for each group of products. That table consisted of specific data related to every product, such as the name of the product, model of the product, quantity of sold units of the product in the observed period, the unit price of the product, unit mass, the total mass of sold units in the observed period, and the total revenue of manufactured units.

Standard accounting information for each group of products in the analyzed company is shown in Table 2.

Step 4. In the implementation of "Circularity Indicators", the De Minimis rule can be applied. This rule permits the exclusion of particular products from the assessment, in case their share in the total mass of products or the total revenue, given in domestic currency, is lower than $5 \%$ (EMAF, 2015). During the analyzed period of 30 days, the mass of sold products was $14,317.60 \mathrm{~kg}$, while the total revenue, given in domestic currency was 4,896,785.00 RSD. The percentage account indicated that $5 \%$ of the total mass was $715.88 \mathrm{~kg}$, and $5 \%$ of the total sales was 244,839.25 RSD.

Both conditions were fulfilled only for the sixth group of products "box for cookies", so in the following steps that group was excluded from the assessment, because its share in the total mass of products was approximately $4.05 \%$, while its share in the total revenue equaled $2.69 \%$.

Step 5. The methodology for determining the circular material indicators at the company level required a reference production approach. Namely, the reference product represented a product, which characterized the whole product range. 
Table 2

Standard accounting information for each group of products

\begin{tabular}{|c|c|c|c|c|c|c|}
\hline Name of product & Model & $\begin{array}{l}\text { Units } \\
\text { sold }\end{array}$ & $\begin{array}{l}\text { Unit price } \\
\text { (RSD) }\end{array}$ & $\begin{array}{l}\text { Unit mass } \\
\quad(\mathrm{kg})\end{array}$ & $\begin{array}{c}\text { Total } \\
\text { mass sold } \\
(\mathrm{kg})\end{array}$ & Total revenue (RSD) \\
\hline \multicolumn{5}{|c|}{ First group of products - cardboard plate } & $3,977.86$ & $\mathbf{1 , 0 7 7 , 3 0 0 . 0 0}$ \\
\hline Cardboard plate & $1 \mathrm{~A}-1 / 25$ & $5,650.00$ & 27.00 & 0.100 & 565.00 & $152,550.00$ \\
\hline Cardboard plate & $2 \mathrm{~A}-1 / 25$ & $3,800.00$ & 29.00 & 0.140 & 532.00 & $110,200.00$ \\
\hline Cardboard plate & $3 \mathrm{~A}-1 / 25$ & $9,760.00$ & 41.00 & 0.160 & $1,561.60$ & $400,160.00$ \\
\hline Cardboard plate & $4 \mathrm{~A}-1 / 25$ & $2,500.00$ & 57.00 & 0.210 & 525.00 & $142,500.00$ \\
\hline Cardboard plate & $1 \mathrm{~B}-1 / 15$ & $3,000.00$ & 27.00 & 0.080 & 240.00 & $81,000.00$ \\
\hline Cardboard plate & $2 \mathrm{~B}-1 / 10$ & $3,470.00$ & 30.00 & 0.090 & 312.30 & $104,100.00$ \\
\hline Cardboard plate & $3 \mathrm{~B}-1 / 10$ & $2,630.00$ & 33.00 & 0.092 & 241.96 & $86,790.00$ \\
\hline \multicolumn{5}{|c|}{ Second group of products - Printed cardboard plate } & $1,607.09$ & $623,750.00$ \\
\hline Printed cardboard plate & $2 \mathrm{~A}-1 / 15$ & $2,945.00$ & 30.00 & 0.082 & 241.49 & $88,350.00$ \\
\hline Printed cardboard plate & $3 \mathrm{~A}-1 / 15$ & $9,000.00$ & 43.00 & 0.120 & $1,080.00$ & $387,000.00$ \\
\hline Printed cardboard plate & $3 \mathrm{~B}-1 / 10$ & $2,800.00$ & 53.00 & 0.102 & 285.60 & $148,400.00$ \\
\hline \multicolumn{5}{|c|}{ Third group of products - Cupcake and cookies liner } & 455.5 & 451,825.00 \\
\hline RAFAELO liner & $1 / 20 / 140$ & 150.00 & 840.00 & 0.850 & 127.50 & $126,000.00$ \\
\hline Cookies liner & No $1-1 / 25 / 100$ & 185.00 & 800.00 & 0.850 & 157.25 & $148,000.00$ \\
\hline Cookies liner & No2-1/25/70 & 180.00 & 700.00 & 0.800 & 144.00 & $126,000.00$ \\
\hline RAFAELO liner & $1 / 20 / 4$ & 200.00 & 45.00 & 0.015 & 3.00 & $9,000.00$ \\
\hline Cookies liner & No1-1/25/4 & 180.00 & 55.00 & 0.025 & 4.50 & $9,900.00$ \\
\hline Cookies liner & No2-1/25/4 & 125.00 & 65.00 & 0.030 & 3.75 & $8,125.00$ \\
\hline Cupcake liner & $\mathrm{M}-1 / 5$ & 310.00 & 80.00 & 0.050 & 15.5 & $24,800.00$ \\
\hline \multicolumn{5}{|c|}{ Fourth group of products - Pads } & $3,181.1$ & $878,770.00$ \\
\hline Pads for rolls & I & $8,500.00$ & 29.00 & 0.095 & 807.50 & $246,500.00$ \\
\hline Pads for cake & No3 & $3,120.00$ & 46.00 & 0.190 & 592.80 & $143,520.00$ \\
\hline Pads for cake & No5 & $2,350.00$ & 55.00 & 0.190 & 446.50 & $129,250.00$ \\
\hline Pads for cake & $\mathrm{No} 2$ & $2,480.00$ & 50.00 & 0.160 & 396.80 & $124,000.00$ \\
\hline Pads for mini roll & MR & $4,500.00$ & 27.00 & 0.075 & 337.50 & $121,500.00$ \\
\hline Pads for cake & C $-1 / 1$ & $3,000.00$ & 38.00 & 0.200 & 600.00 & $114,000.00$ \\
\hline \multicolumn{5}{|c|}{ Fifth group of products - Boxes for rolls and cakes } & $3,245.00$ & $884,250.00$ \\
\hline Box for mini rolls & I & $2,750.00$ & 32.00 & 0.115 & 316.25 & $88,000.00$ \\
\hline Cake box & No1 & $2,000.00$ & 20.00 & 0.100 & 200.00 & $40,000.00$ \\
\hline Box for cake & $\mathrm{No} 2$ & $3,000.00$ & 55.00 & 0.170 & 510.00 & $165,000.00$ \\
\hline Box for cake & No4 & $2,500.00$ & 60.00 & 0.200 & 500.00 & $150,000.00$ \\
\hline Box for cake & No5 & $2,500.00$ & 59.00 & 0.250 & 625.00 & $147,500.00$ \\
\hline Box for rolls & $\breve{\mathrm{S}}-1 / 1$ & $6,250.00$ & 47.00 & 0.175 & $1,093.75$ & $293,750.00$ \\
\hline \multicolumn{5}{|c|}{ Sixth group of products - Box for cookies } & 580.25 & $131,750.00$ \\
\hline Box for cookies & No2 1/2 kg & $4,000.00$ & 11.00 & 0.050 & 200.00 & $44,000.00$ \\
\hline Box for cookies & No3 $1 \mathrm{~kg}$ & $5,850.00$ & 15.00 & 0.065 & 380.25 & $87,750.00$ \\
\hline \multicolumn{5}{|c|}{ Seventh group of products - Boxes for cookies/cakes with an opening } & 547.5 & $254,000.00$ \\
\hline Box for cookies & No1 $1 / 2 \mathrm{~kg}$ & $2,500.00$ & 16.00 & 0.035 & 87.50 & $40,000.00$ \\
\hline Box for cookies & No2 $1 \mathrm{~kg}$ & $4,000.00$ & 20.00 & 0.045 & 180.00 & $80,000.00$ \\
\hline Box for cake & No3 & $2,000.00$ & 67.00 & 0.140 & 280.00 & $134,000.00$ \\
\hline \multicolumn{5}{|c|}{ Eight group of products - "Party" program } & 723.3 & $595,140.00$ \\
\hline Birthday hat 1/6 & $1 / 6$ & $3,900.00$ & 44.80 & 0.075 & 292.50 & $174,720.00$ \\
\hline Birthday cup 1/10 & $1 / 10$ & $3,120.00$ & 45.00 & 0.055 & 171.60 & $140,400.00$ \\
\hline Party set $3 / 10$ & $3 / 10$ & $1,890.00$ & 58.00 & 0.080 & 151.20 & $109,620.00$ \\
\hline Birthday trumpet $1 / 6$ & $1 / 6$ & $2,400.00$ & 71.00 & 0.045 & 108.00 & $170,400.00$ \\
\hline \multicolumn{5}{|c|}{ Total } & $14,317.60$ & $4,896,785.00$ \\
\hline
\end{tabular}


In this assessment, the following products were selected as the reference products:

- Cardboard plate 3A-1/25,

- Printed cardboard plate 3A-1/15,

- Cookies liner No 1/25/100,

- Cake pads /,

- Box for roll $\breve{S}-1 / 1$,

- Box for cake No3,

- Birthday hat $1 / 6$.

Products whose demand was the highest in the observed period were chosen for the reference products.

Step 6. In this research, for each reference product, the table "bill of materials" was created.

A bill of materials is a list of the parts or components that are required to build a product (EMAF, 2015). That list included data on materials and mass of material which went into the process of production. A bill of materials provided information related to recycled or reused materials and also information about the predicted share of materials that could be recycled or reused after the phase of product use. The bills of materials for the seven reference products are shown in Table 3.

Table 3

Bill of materials for the reference products

\begin{tabular}{|c|c|c|c|c|c|c|}
\hline Component & Material & $\begin{array}{c}\text { Mass } \\
{[\mathrm{kg}]}\end{array}$ & $\begin{array}{l}\% \text { recycled } \\
\text { feedstock }\end{array}$ & $\begin{array}{l}\text { \% reused } \\
\text { feedstock }\end{array}$ & $\begin{array}{c}\% \text { recycled } \\
\text { after use }\end{array}$ & $\begin{array}{l}\% \text { reused } \\
\text { after use }\end{array}$ \\
\hline \multicolumn{7}{|c|}{ Cardboard plate $3 A-1 / 25$} \\
\hline Plate & Cardboard & 0.1575 & 97.00 & 0.00 & 100.00 & 0.00 \\
\hline Label & White paper & 0.0005 & 0.00 & 0.00 & 100.00 & 0.00 \\
\hline Bag & PE foil & 0.0020 & 25.00 & 0.00 & 100.00 & 0.00 \\
\hline \multicolumn{7}{|c|}{ Printed cardboard plate $3 A-1 / 15$} \\
\hline Plate & Card board & 0.1145 & 97.00 & 0.00 & 100.00 & 0.00 \\
\hline Label & White paper & 0.0005 & 0.00 & 0.00 & 100.00 & 0.00 \\
\hline Bag & PE foil & 0.0020 & 25.00 & 0.00 & 100.00 & 0.00 \\
\hline Deco layer & Color & 0.0030 & 0.00 & 0.00 & 0.00 & 0.00 \\
\hline \multicolumn{7}{|c|}{ Cookies liner No 1/25/100 } \\
\hline Cookies liner & Pergament paper & 0.750 & 0.00 & 0.00 & 0.00 & 0.00 \\
\hline Label & White paper & 0.0005 & 0.00 & 0.00 & 100.00 & 0.00 \\
\hline Deco layer & Color & 0.0095 & 0.00 & 0.00 & 0.00 & 0.00 \\
\hline Box & PET & 0.090 & 0.00 & 0.00 & 100.00 & 100.00 \\
\hline \multicolumn{7}{|c|}{ Cake pads / } \\
\hline $\mathrm{Pad}$ & Cardboard & 0.0919 & 85.00 & 0.00 & 100.00 & 0.00 \\
\hline Label & White paper & 0.0005 & 0.00 & 0.00 & 100.00 & 0.00 \\
\hline Deco layer & Deco Pe foil & 0.0008 & 0.00 & 0.00 & 50.00 & 0.00 \\
\hline Contact layer & Contact glue & 0.0008 & 0.00 & 0.00 & 0.00 & 0.00 \\
\hline Bag & PE & 0.0010 & 50.00 & 0.00 & 100.00 & 100.00 \\
\hline \multicolumn{7}{|c|}{ Box for roll $\breve{S}-1 / 1$} \\
\hline Box & Cardboard & 0.1715 & 97.00 & 0.00 & 100.00 & 0.00 \\
\hline Label & White paper & 0.0005 & 0.00 & 0.00 & 100.00 & 0.00 \\
\hline Contact layer & Contact glue & 0.0020 & 0.00 & 0.00 & 0.00 & 0.00 \\
\hline Bag & PE & 0.0010 & 50.00 & 0.00 & 100.00 & 100.00 \\
\hline \multicolumn{7}{|c|}{ Box for cake No3 } \\
\hline Box & Cardboard & 0.1365 & 97.00 & 0.00 & 100.00 & 0.00 \\
\hline Label & White paper & 0.0005 & 0.00 & 0.00 & 100.00 & 0.00 \\
\hline Contact layer & Contact glue & 0.0020 & 0.00 & 0.00 & 0.00 & 0.00 \\
\hline Opening & PE foil & 0.001 & 25.00 & 0.00 & 100.00 & 0.00 \\
\hline \multicolumn{7}{|c|}{ Birthday hat 1/6 } \\
\hline Hat & Cardboard & 0.0695 & 97.00 & 0.00 & 100.00 & 0.00 \\
\hline Label & White paper & 0.0005 & 0.00 & 0.00 & 100.00 & 0.00 \\
\hline Deco layer & Color & 0.0020 & 0.00 & 0.00 & 0.00 & 0.00 \\
\hline Bag & $\mathrm{PE}$ & 0.0010 & 50.00 & 0.00 & 100.00 & 100.00 \\
\hline Contact layer & Contact glue & 0.0020 & 0.00 & 0.00 & 0.00 & 0.00 \\
\hline
\end{tabular}




\section{A. Pavlović et al.}

As already emphasized, the circularity at the level of the reference product was determined first. Therefore, the share of materials used in the production process for a reference product should be calculated as well as the possible level of recycling and reuse of the material after the product use phase. Namely, these percentages were expressed in table 3, but especially for each component, which was integrated into the product mass. The necessary data for the product was determined using the arithmetic mean given in equation 13 .

$$
\bar{X}=\frac{\sum_{i=0}^{n} x_{i}}{n}
$$

In the previous equation, the numerator represented the sum of all the results in the sample, while the denominator represented the number of samples.

So, according to this statistical technique, Table 3 was then transformed into Table 4.

Step 7. In this step, the real lifetime of the reference product should be defined as well as the average lifetime of a similar competitor's product, the actual number of functional units, and the average number of functional units of a similar competitor's product.

If it was not possible to ensure a reliable estimation of a lifetime and the number of functional units, it was necessary to acknowledge that these parameters were equal and that their ratio equaled 1 (EMAF, 2015). In this case, all the mentioned parameters were equivalent to 1 .

It is important to emphasize that parameters of recycling process efficiency at the end of life and efficiency of the recycling for feedstock were established according to the report published by the "Deutsche Gesellschaft für Internationale Zusammenarbeit" (GIZ) (Bobić, 2019).

Step 8. Using the mathematical formulas from chapter 4, $M C I_{P}$ and $L F I_{P}$ were determined for each reference product. The assessment was done using Microsoft Excel software. The example of a table which was used for evaluation is shown in Table 5.

Table 4

Bill of materials for the reference products

\begin{tabular}{lccccc}
\hline Reference product & Mass & $\begin{array}{c}\text { \% recycled } \\
\text { feedstock }\end{array}$ & $\begin{array}{c}\text { \% reused } \\
\text { feedstock }\end{array}$ & $\begin{array}{c}\text { \% recycled } \\
\text { after use }\end{array}$ & $\begin{array}{c}\text { \% reused } \\
\text { after use }\end{array}$ \\
\hline Cardboard plates 3A-1/25 & 0.16 & 40.67 & 0.00 & 100.00 & 0.00 \\
Printed cardboard plate 3A-1/15 & 0.12 & 30.50 & 0.00 & 75.00 & 0.00 \\
Cookies liner No 1/25/100 & 0.085 & 0.00 & 0.00 & 50.00 & 25.00 \\
Cake pads / & 0.095 & 27.00 & 0.00 & 70.00 & 20.00 \\
Box for roll Š-1/1 & 0.175 & 36.75 & 0.00 & 75.00 & 25.00 \\
Box for cakes with an opening No 3 & 0.140 & 30.50 & 0.00 & 75.00 & 0.00 \\
Birthday hat 1/6 & 0.075 & 29.40 & 0.00 & 60.00 & 20.00 \\
\hline
\end{tabular}

Table 5

Evaluating MCI of Reference product: Cardboard plates 3A-1/25

\begin{tabular}{|c|c|c|c|}
\hline Metrics for core sustainability indicators & & Data & Units \\
\hline Product total mass $(\mathrm{M})$ & & 0.16 & $\mathrm{~kg}$ \\
\hline Product mass from recycled feedstock $(\mathrm{Fr})$ & & 40.67 & $\%$ \\
\hline Product mass from reused components $(\mathrm{Fu})$ & & 0.00 & $\%$ \\
\hline Product sent for recycling at end of life $(\mathrm{Cr})$ & & 100.00 & $\%$ \\
\hline Product sent for reuse at end of life $(\mathrm{Cu})$ & & 0.00 & $\%$ \\
\hline Efficiency of recycling process at the end of life (Ec) & & 40.00 & $\%$ \\
\hline Efficiency of recycling process for feedstock (Ef) & & 55.00 & $\%$ \\
\hline Product lifetime OR Product use (L or U) & & 1.00 & Yr \\
\hline \multirow[t]{3}{*}{ Industry average lifetime $\mathbf{O R}$ industry average use (Lav or Uav) } & & 1.00 & Yr \\
\hline & $\begin{array}{c}\text { Linear Flow Index } \\
\text { (LFI) }\end{array}$ & 0.57 & \\
\hline & $\begin{array}{c}\text { Material } \\
\text { Circularity } \\
\text { Indicator (MCI) }\end{array}$ & 0.49 & \\
\hline
\end{tabular}




\section{A. Pavlović et al.}

Step 9. The ninth step involved defining normalization factors which were determined for every reference product. In this case, the normalizing factor was used to aggregate material circularity indicators for the reference product. For that purpose, the mass of the product group was taken as a normalization factor. After completion of the steps eight and nine, it was possible to define precisely the circularity levels for the reference products. Results of $M C I_{P}$ are shown in Table 6.
Recycling and Sustainable Development 13 (2020) 09-21

Step 10. The mathematical combining of $M C I_{P}$ was done at the level of the product in order to calculate the level of circularity of the company $M C I_{C}$. Above mentioned combination was done according to equation 12 and the final obtained result was 0.47 .

Results of calculations are shown in Figure 1, indicating that the company operated using a business model which was in the between linear and circular model.

Table 6

Results of $\mathrm{MCI}_{\mathrm{P}}$ for reference products

\begin{tabular}{lcc}
\hline Name of product's group & Mass of the group of product [kg] & MCI $_{P}$ \\
\hline Cardboard plate & $3,977.86$ & 0.49 \\
Printed cardboard plate & $1,607.09$ & 0.39 \\
Cupcake and cookies liner & 455.50 & 0.32 \\
Pads & $3,181.10$ & 0.46 \\
Boxes for rolls and cakes & $3,245.00$ & 0.53 \\
Boxes for cakes with an opening & 547.50 & 0.39 \\
Party program & 723.30 & 0.44 \\
\hline
\end{tabular}

Material circularity indicator of the company

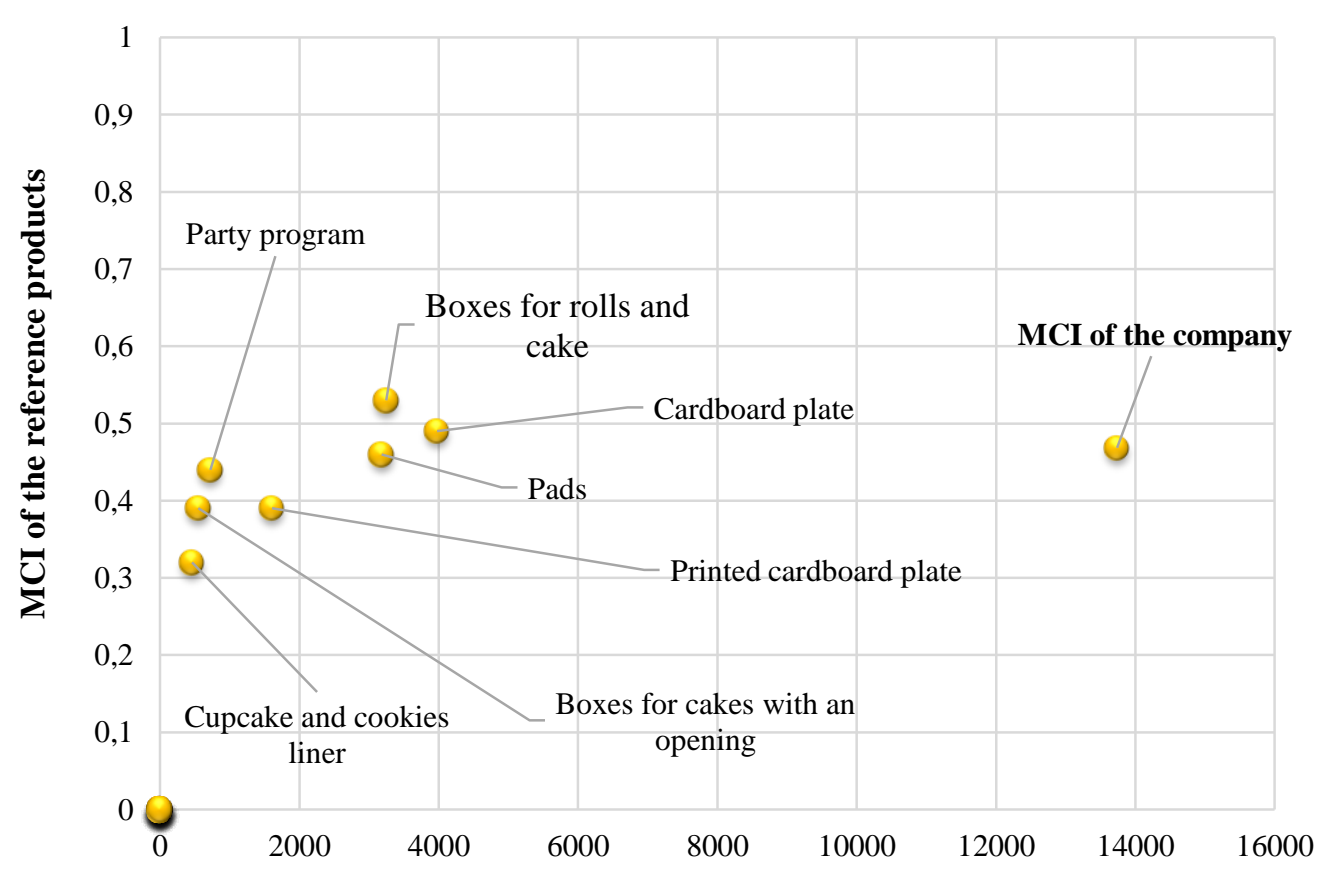

Mass of the products [kg]

Figure 1. Results of circularity level in the analyzed company (Pavlović et al., 2018) 


\section{Measures for improving circularity indicators in analyzed company}

To achieve complete implementation of the circular economy, changes in the way of production and consumption of the products are necessary.

Promoting a CE in companies that operate in Serbia is not only a key for Serbia's integration into the EU, but also, it is an opportunity for innovation, efficient use of resources, participation in numerous researches, and financial programs, etc. The CE seeks a different manner related to waste management and recycling, as well as increased discipline in respecting the guidelines for such directives and improved monitoring of waste flows.

The obtained value of the Circular Indicator for "MB INTERNACIONAL" was approximately 0.47 , which means that the company can proceed with specific measures, which will improve the circularity level.

Figure 2 shows the necessary steps that should be taken in order to transform the company's business model from a linear to a circular.

So far, the company "MB INTERNACIONAL" has not performed any actions related to the development of a circular economy. Still, the company's main activity is such that it uses organic raw materials in its production process, which affects a higher level of circularity. After the performed evaluation of circularity, it is necessary to carry out "benchmarking", i.e., to explore and discover the advantages and examples of good CE practices of competing companies, which should be applied afterward.

Switching from a linear business model to a circular is a complex process, which involves constant monitoring and improvements. Company "MB INTERNACIONAL" can implement specific measures to improve the level of circularity, which can be low-budget or high-budget.

The first reason for the development of the CE in the company is the phenomenon of improvement of the brands' reputation, and thereby, the company becomes more competitive in the market.
Low-budget measures may even include the introduction of eco-design into the company's business model. Eco-design implies the creation of such a product, which, during its life cycle, has a minimal negative impact on the environment. This type of product design is reflected in the design of new, more energy-efficient products, which will be produced from $100 \%$ biodegradable materials, and materials that allow the reuse of these products, or recyclable materials.

Due to environmental protection, the company "MB INTERNACIONAL" has to promote the recycling of paper and paperboard, because it saves forests, energy used for the production process, and the most important, there is no generation of methane.

However, for the analyzed case study, there was a recycling problem after the product use phase. The company carries out the production of cardboard packaging and the packaging used for storing food, so after the use phase the products are damaged by the rest of the food, which makes the recycling process more difficult. Solving this problem can be composting waste paper or paperboard.

Another way of improving the $\mathrm{CE}$ in the company is the introduction of an efficient environmental management system.

Also, the company must optimize the generated amount of waste in the production process.

One of the high-profile measures that can improve the company's circularity is a purchase of a hydraulic press for baling fibrous materials. That way, the waste would be treated within the company itself, and then the company could sell the newly created product to factories, which mainly manufacture materials from recycled paper or cardboard waste.

Implementing the $\mathrm{CE}$ in the company "MB INTERNACIONAL" is possible, as well as improvement of the same. For the implementation of the CE, it is necessary to identify critical phases of the product's life cycle in the analyzed company. That can be done by using the "Circular Economy Toolkit - CET."

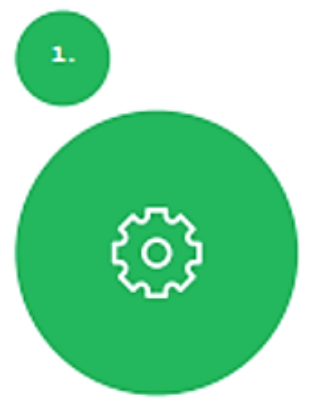

Analyze material flow in the company

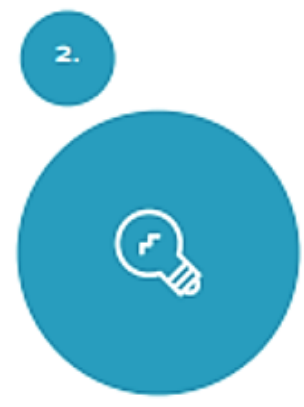

Consider an innovative circular business model

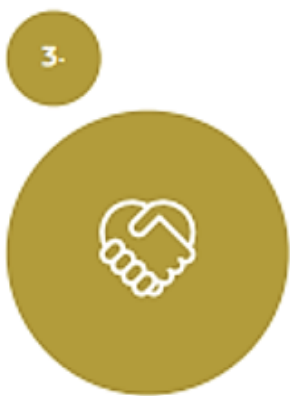

Incorporate staff and shareholders into consideration of new ideas

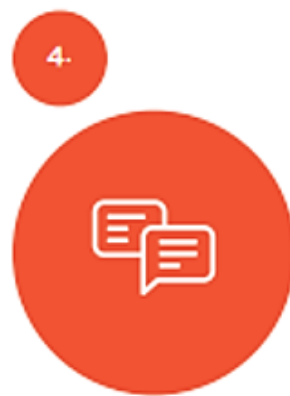

Create a strategy and action plan on the circular economy

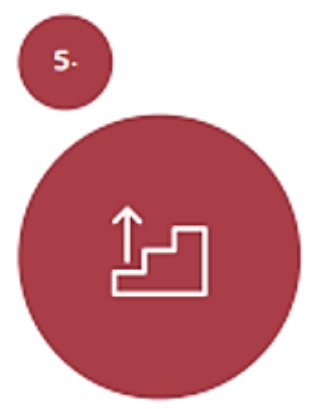

Based on evaluation and research, define improvement measures

Figure 2. Path of transition to a $\mathrm{CE}$ in one single company 
CET is developed at the University of Cambridge. The CET is an assessment tool to identify the potential improvement of the products' circularity (Evans and Bocken, 2014). This is a fast online tool which the companies use to evaluate the improvement potential of products towards circularity.

For the analyzed company, the CET was done, and the outcome is shown in Table 7.

CET can identify the most important and critical phases of the product's life cycle. As stated, companies have insight into the areas with a high, medium, or low potential for the improvement of the circularity activities, as shown in Table 6 for the "MB INTERNACIONAL" company.

Transformation to $\mathrm{CE}$ requires changes in number of organizational dimensions, such as value creation, customer segments, and innovation activity (Primc et al., 2020). In order to develop and sharpen the concept of a circular economy, it is necessary to affect the consumers' way of thinking and then change the business model. Consumers have an essential role in the CE, which leads to a conclusion that the transition of a consumption model of a product is of great importance and it must be carried out first.

Table 7

Result of the Circular Economy Toolkit

\begin{tabular}{lc}
\hline Improvement Area & Improvement Potential \\
\hline Reduce materials & High opportunity \\
Optimize materials & Medium opportunity \\
Industrial Symbiosis & High opportunity \\
Usage & High opportunity \\
Maintain/Repair & High opportunity \\
Reuse/Redistribute & High opportunity \\
Refurbish/Remanufacture & Medium opportunity \\
Product Recycling & Medium opportunity \\
Product as a Service & Medium opportunity \\
\hline
\end{tabular}

\section{Conclusion and future work}

The circular economy model is an essential model for managing resources more efficiently. The researched model is useful for creating a regenerative economy that has positive economic and environmental effects. The application of a circular economy model implies a transformation of the whole system of waste management. It is a systematic change that is necessary for the development of the Republic of Serbia in the environmental field. The main advantage of the implementation of the CE in the Republic of Serbia can be explained by the fact that it creates resource efficiency, promotes renewable energy, and enables cleaner production, which moves towards zero waste.

Contrary to that, the main disadvantage of the proposed methodology can be noted as the lack of legislation in the field of the CE. Simultaneously, that is the main reason why companies in Serbia still do not admit the CE as a chance for future development.

After implementing the methodology "Circularity Indicators" in the specific company that operates in Serbia, it is concluded that the CE was not total newness - because the obtained value of $M C I$ was 0.47 . This means that the company operates according to the economic model, which is between linear and circular.

Using specific measures that can be low-budget or high-budget, the analyzed company can improve the current economic model.

It has been said before that there is a deficit of research on the topic of evaluating the circularity level in the companies in Serbia, so this research checked if it was possible to adopt methodology launched by EMAF in Serbian policy. Obtained results in the specific company led to the general conclusion that methodology could be implemented in companies that operate in Serbia because their management had all the data needed to determine the level of circularity.

The methodological approach for determining the circularity at the company's level is essential for numerous estimates and indicators. The most common performance assessment of an organization is done using the so-called key performance indicators (KPIs). The KPIs should be related to the company's strategic goals (finance, market, processes, and people) but also considering the circularity goals.

Further research in the CE field should be carried out in a more significant number of companies. Also, it is proposed to develop or implement new indicators, which will determine the circularity level. For developing new projects and researches in fields of the CE in the Republic of Serbia, it is needed to train industrial experts in product circularity assessment, as well as establish indicators and tools for measurement and monitoring of circularity.

\section{Acknowledgement}

This research has been supported by the Ministry of Education, Science and Technological Development, Republic of Serbia (Project III 42013). Work of Natalia Sliusar and Nemanja Stanisavljevic is financially supported by the Government of the Perm region, Russia, within the framework of research project no. C-26/174.6.

\section{References}

Andrews D., The circular economy, design thinking and education for sustainability: Local Economy, 30 (3), 2015, 305-315,

Bobić D., Circular Economy Impact Assessment-Plastic Packaging sector, Deutsche Gesellschaft für Internationale Zusammenarbeit (GIZ) GmbH, Belgrade, Serbia, 2019, 37, ISBN 987-86-80390-35-2, 
Bracquené E., Dewulf W., Duflou J. R., Measuring the performance of more circular complex product supply chains, Resources, Conservation and Recycling, 154, 2020, 104608,

Cayzer S., Griffiths P., Beghett V., Design of indicators for measuring product performance in the circular economy: International Journal of Sustainable Engineering, 10 (4-5), 2017, 289-298,

Đureta V., Mutić M., Mitrović S., Bogdanović M., The basics of Circular Economy, Deutsche Gesellschaft für Internationale Zusammenarbeit (GIZ), (In Serbian language), Belgrade, 2016, 25,

Đurić S., Stošić-Mihajlović Lj., Trajković S., Circular economy and create new values - recycling, renewable energy, ecology, Journal of Process Management - New Technologies, International, 5 (3), 2017, 50-68,

Dwek M., Integration of material circularity in product design, (Disertation), Université Grenoble Alpes, Grenoble, France, 2017, 243,

El-Haggar S. M., Sustainable Development and Industrial Ecology, Sustainable Industrial Design and Waste Management, Chapter 3, 2007, 85-124, ISBN13: 978-0-12-373623-9,

EMAF - Ellen MacArthur Foundation, Circularity indicators - An approach to measuring circularity, London, United Kingdom, 1, 2015, 98,

EMAF - Ellen MacArthur Foundation, Intelligent assets: unlocking the circular economy potential, London, United Kingdom, 1, 2016, 39,

EMAF - Ellen MacArthur Foundation, Towards the circular economy: Economic and business rationale for an accelerated transition, London, United Kingdom, 1, 2013, 96,

European Commission, Circular Economy Action Plan For a cleaner and more competitive Europe, Brussels, EU, 2020, 28,

European Commission, Closing the loop - An EU action plan for the Circular Economy, Brussels, EU, 2015, 21 ,

European Commission, EU Monitoring Framework for the Circular Economy, Strasbourg, EU, 2018, 11,

Evans J., Bocken N., A tool for manufacturers to find opportunity in the circular economy www.circulareconomytoolkit.org, International Conference on Sustainable Design and Manufacturing, Wales, UK, April 2014, 303-320, Editors: Setchi R., Howlett R.J., Naim M. and Seinz H., Publisher: Future Technology Press, England, UK, ISBN 978-0-9561516-5-0,

Ghisellini P., Ulgiati, S., Circular economy transition in Italy: Achievements, perspectives and constraints. Journal of Cleaner Production, 2020, 118360,

Kalmykova Y., Sadagopan M., Rosado L. Circular economy - From review of theories and practices to development of implementation tools, Resources, Conservation and Recycling, 135, 2018, 190-201,
Kirchherr J., Reike D., Hekkert M., Conceptualizing the circular economy: An analysis of 114 definitions, Resources, Conservation and Recycling, 127, 2017, 221-232,

Kraaijenhagen C., Van Oppen C., Bocken N., Circular Business: Collaborate and Circulate, Chapter 1, Circular Collaboration, 2016, ISBN: 978-90-824902$0-6$,

Levoso A. S., Gasol C. M., Martínez-Blanco J., Durany X. G., Lehmann M., Gaya R. F., Methodological Framework for the Implementation of Circular Economy in Urban Systems, Journal of Cleaner Production, 2019, 119227,

Marvuglia A., Santagata R., Rugani B., Benetto E., Ulgiati S., Emergy-based indicators to measure circularity: promises and problems, Energy Policy Journal, 21 (4), 2018, 179-196,

McDowall W., Geng Y., Huang B., Barteková E., Bleischwitz R., Türkeli S., Kemp R., Doménech, T. , Circular Economy Policies in China and Europe, 21 (3), 2017, 651-661,

Morseletto P., Targets for a circular economy. Resources, Conservation and Recycling, 153, 2020, 104553,

Patwa N., Sivarajah U., Seetharaman A., Sarkar S., Maiti K., Hingorani K., Towards a circular economy: An emerging economies context, Journal of Business Research, 2020, Article in press,

Pavlović A., Bošković G., Jovičić N., Nestić S., Stanisavljević N., The possibility of implementing circular economy in companies in the Republic of Serbia, 3rd International Conference on Quality of Life, Kopaonik, Serbia, November 2018, 105-112, Editors: Arsovski S Stefanović M and Tadić D, Publisher: Faculty of Engineering, University of Kragujevac, ISBN 978-86-6335-056-4,

Pearce D., Turner K., Economics of natural resources and the environment, Johns Hopkins University Press, 1990, 396, ISBN 978-0801839870,

Primc K., Kalar B., Slabe-Erker R., Dominko M., Ogorevc M., Circular economy configuration indicators in organizational life cycle theory, Ecological Indicators, 116, 2020,106532,

Radivojević A., Circular economy: Implementation and technology application in its function, (In Serbian language), Journal Economic Ideas and Practice, Faculty of Economics, University of Belgrade, 28, 2018, 33-46,

Razza F., Briani C., Breton T., Marazza D, Metrics for quantifying the circularity of bioplastics: The case of bio-based and biodegradable mulch films. Resources, Conservation and Recycling, 159, 2020, 104753,

Saidani M., Monitoring and advancing the circular economy transition - Circularity indicators and tools applied to the heavy vehicle industry (Disertation), Université Paris-Saclay, France, 2018, 241,

Solaja O., Challenges and Prospects of Small and Medium Ecopreneurs (SMEcos) in Contemporary 
Nigerian Circular Economy, Recycling and Sustainable Development, 12, 2019, 1-11,

Ullstein B., Walkowiak B.B, Gillabel J., Wahlström M., Ylijoki J.L., Nelen D., Geerken T., Van Hoof V., Dils E., Kazmierczyk P., Montalvo D., Resource efficiency and circular economy in Europe - even more from less: An overview of policies, approaches and targets of Serbia in 2018, The European Topic Centre on Waste and Materials in a Green Economy, 2019, 26,
United Nations, Department of Economic and Social Affairs, Population Division, World Population Prospects 2019 - Highlights, (ST/ESA/SER.A/423), 2019, New York, SAD, 46, ISBN 978-92-1-148316-1,

Vercalsteren A., Christis M., Van Hoof V., Indicators for a Circular Economy, Department of economy science and innovation, $\mathrm{CE}$ Center - Support Center for Circular Economy, 2018, 42.

\title{
Određivanje indikatora cirkularne ekonomije - studija slučaja kompanije „MB INTERNACIONAL"
}

\author{
Angelina Pavlović a, \#, Goran Bošković a, Nebojša Jovičić a, Snežana Nestić a, \\ Natalia Sliusar ${ }^{\mathrm{b}}$, Nemanja Stanisavljević ${ }^{\mathrm{c}}$ \\ ${ }^{a}$ Univerzitet u Kragujevcu, Fakultet inženjerskih nauka, Srbija \\ ${ }^{\mathrm{b}}$ Nacionalni politehnički univerzitet za istraživanje u Permu, Odeljenje za zaštitu životne sredine, Rusija \\ ${ }^{c}$ Univerzitet u Novom Sadu, Fakultet tehničkih nauka, Srbija
}

\section{INFORMACIJE O RADU}

Primljen 30 jun 2020

Prihvaćen 25 septembar 2020

Originalan rad

Ključne reči:

Cirkularna ekonomija

Indikatori cirkularne ekonomije

Indikator cirkularnosti materijala

Održivi razvoj

Proširena i recenzirana verzija rada rad prezentovan na simpozijumu 3. ICQL

\section{Z V O D}

Cirkularna ekonomija (skraćeno CE) je trenutno svetski popularan koncept koji bi trebalo da osigura održivi razvoj i efikasnost resursa. Koncept je zasnovan na teoriji potrošnje i upotrebe resursa u postupku proizvodnje na način koji utiče na ograničavanje štetnih efekata na životnu sredinu. Ovaj koncept istovremeno stvara dodatnu vrednost proizvoda i omogućava njegovo ponovno korišćenje. U Republici Srbiji je ideja o cirkularnoj ekonomiji još uvek nova i nerazvijena. Stoga, cilj ovog rada je da istraži mogućnost primene CE u kompanijama koje posluju u Srbiji usvajanjem metodologije koja je već razvijena u Evropskoj uniji. Ovo istraživanje je sprovedeno u kompaniji „MB INTERNACIONAL“ koja proizvodi kartonsku ambalažu gde je praćen proizvodni postupak. Dobijena približna vrednost indikatora cirkularne ekonomije je iznosila 0,47 , što ukazuje na to da kompanija ima odličnu šansu za potpunu primenu modela cirkularne ekonomije u poslovanju uz primenu posebnih mera. Niskobudžetne i visokobudžetne mere koje bi doprinele povećanju nivoa cirkularnosti $\mathrm{u}$ analiziranoj kompaniji su takođe predstavljene u ovom radu. 